\title{
CSR Practices and the Political Corporation in Law
}

\author{
Anna Beckers
}

In her article 'Corporate Social Responsibility: The Great Shell Game', Ellen Hertz suggests that there is an inherent danger of corporate social responsibility (CSR) to obscure the public/private divide. By means of strategically engaging with public interests, corporate CSR practices - that according to Hertz are practices deriving from the market - are able 'to preempt and discredit attempts to define and carry out policies designed to protect the broader public interest'. CSR should be seen as 'remediation at best' that ideally needs to be replaced by 'rules for business' created by 'the public' and not those created by companies themselves.

My comment focuses on and questions the central assumption itself that underlies Hertz' position: The observed obfuscation of the public/ private divide through corporations and their CSR practices and her related conclusion that market and politics need to be kept separate in order to regulate corporations through law proper. Taking a legal perspective, I seek to demonstrate that the law never subscribed to a similarly strict divide between the public and the private sphere when conceptualizing corporations legally. Relatedly, I argue that rather than being a set of practices whereby corporations dangerously interfere with politics, CSR can be understood as a political practice in itself that may be translated as such in legal form.

\section{Firms/markets versus corporations}

The first fundamental difference between Hertz' and my position is her trust in a clear market/politics divide and, in line with Milton Friedman, the allocation of companies to the sphere of the market that should be kept out of politics (and law-making). Yet, in legal scholarship, company lawyers have already deconstructed as descriptively and normatively inaccurate this Friedmanian 'myth' that the business of business is and 
should be business. Businesses are not only economic entities that operate on the market with a presumed interest to make profits on which regulatory constraints can be imposed. As corporations, they are entities created by the legal system. The history of corporate law has shown a remarkable transformation of the corporate image, that is, its nature and purpose, that range from an equalizing with state interests in early concession theory, to atomizing it to individualized market relations in nexus of contracts theory and classical agency theory to a recent revival of re-integrating public interest elements into corporate law and purpose (Deakin 2017). In this regard, it is crucial to emphasize that the legal rules as such did not and still do not equalize the corporate interest with shareholder value, profit-maximization, or even broadly the demands of the market (Robé 2012; Sjåfjell et al. 2015; Stout 2008). The law defines the interest and purpose of the company autonomously and, for that purpose, it is able to integrate a 'company interest' that considers wider social interests.

\section{CSR practice as politicization of corporations, contested}

This leads me to the role of corporate CSR practices, on which Hertz and I appear to disagree as well. To me, there is not enough evidence to assume that CSR practices are only or primarily market practices by companies aimed at discrediting democracy. I do take note of the various anthropological approaches that Hertz relies on and take seriously the critical description of CSR as bureaucratic accounting practices, strategic tools for reputation management, depoliticizing efforts for social movements and tactical steps to preempt governmental regulation; yet, such practices represent arguably only one dimension of CSR. The reverse side is constant contestation through, amongst others, civil society, political regulation, and strategic litigation. In social, political, and legal theory, CSR is therefore described as a form of contested governance (Bair and Palpacuer 2015; Levy and Kaplan 2008), as an in-between world of politics, the economy, and law (Kjaer 2011) or an inner-politicization of corporations that takes legal form (Backer 2013; Beckers 2015; Teubner 2012). CSR is an institutional practice within corporations that indicates formalized yet fluid 'rough consensus and running code' on the corporate purpose (Calliess and Zumbansen 2010). Accordingly, CSR practices are the hard and stable corporate constitution implemented and enforced within the corporation (Herberg 2008; Teubner 2011) while being constantly subject to dissent that results 
in change in their content, implementation and scope. On the point of fluidity, Hertz and I seem to agree, as she is also emphasizing the character of CSR as 'constantly evolving in response to the demands of "the market for virtue"'. Yet I argue that this constant change is not, as she interprets, a response solely to market demands; it is response to political contestation by the society in which companies are operating. Following the theory of the political difference (Marchart 2007), CSR practices are not a form of (undemocratic) politics; yet, they are inherently political.

Arguably, this conflict-laden understanding may better grasp the normative backdrop of CSR practices as discussed in this special issue (see Eckert and Knöpfel this issue). Legislators that increasingly require companies not only to develop, implement, and communicate CSR practices, but also specify the content, form, and scope of such practices; courts that slowly take up CSR policies as potential arguments in litigation for creating obligations for corporations and creating liability (and the limits thereof); or certification schemes that are an integral part of corporate CSR practices, but at the same time, become sites of institutional contestation that pave the way for new types of responsibility attributions (Eller 2017).

As a result, CSR is not an interference of market-driven soft, strategic, and bureaucratic CSR practices with politics and law, but a political space that is created by and within CSR practices. The legal question is then not about creating rules for corporations through law proper, but rather to reflect this political dimension in the legal categories of obligations and liability that apply to corporations.

\section{The role of anthropologists and lawyers}

This finally suggests a different research agenda for anthropologists and lawyers. Anthropologists are very well equipped to analyse the struggles behind creating and contesting CSR within and outside the corporation. They may reveal the bureaucratizing tendencies, but equally the hopes, dissent, or resistance by those affected by corporate activities. However, rather than embedding this within a 'top-down' vision that places CSR practices a priori within the framework of market, such investigation can also embrace the idea of making visible alternative versions and perceptions of CSR practices and shed light into their normative potential. Lawyers may then take up such insights to see where such normative potential bottom-up becomes 
legally significant and what obligations it may create. A good example for such anthropological groundwork with legal implications is the rich anthropological insight of how CSR practices in companies travel from the parent company headquarter to the ground level in subsidiaries or even through globally dispersed supply chains and what type of expectations they create. Such insights can help analyse from a legal perspective to what extent legal rights are created for affected parties against companies (see Knöpfel 2019; Zumbansen 2019), a suggestion that is increasingly also becoming an issue in courts (see recently Lungowe v. Vedanta Resources, [2019] UKSC 20, paras 52-55). CSR practices may contain normative promises for a constitutionalisation of corporations 'on the ground' that anthropologists are well equipped to reveal in their field work. Legal scholars can then integrate such an alternative, non-market vision of CSR as part of its own system of rules, a system that is ambiguous precisely because it creates rights of corporations and, through limiting principles as separate legal personality and privity of contract, serves as a basis for global capitalist structures (Pistor 2019), but at the same time also contains tools for creating new legal obligations. As an observer has it: 'Bringing legal arguments, within the [existing] juridical system, that aim to expand responsibility, argues for a potentially different reading of the law, which would also translate in different economic realities' (Saage-Maaß 2020). CSR practices can be part of such legal arguments.

Anna Beckers is Assistant Professor of Private Law and Legal Methodology at Maastricht University, The Netherlands.

Email: anna.beckers@maastrichtuniversity.nl

\section{References}

Backer, L. C. (2013), 'Transnational corporations' outward expression of inward self-constitution: The enforcement of human rights by Apple, Inc.', Indiana Journal of Global Legal Studies 20: 805-879.

Bair, J. and F. Palpacuer (2015), 'CSR beyond the corporation: contested governance in global value chains', Global Networks: A Journal of Transnational Affairs 15: S1-19.

Beckers, A. (2015), Enforcing Corporate Social Responsibility Codes: On Global Self-Regulation and National Private Law (Oxford: Hart Publishing).

Calliess, G.-P. and P. Zumbansen (2010), Rough Consensus and Running Code. A Theory of Transnational Law (Oxford: Hart Publishing) 
Deakin, S. (2017), 'The corporation in legal studies', in G. Baars and A. Spicer (eds), The Corporation: A Critical, Multi-Disciplinary Handbook (Cambridge: Cambridge University Press), 47-63.

Eller, K. H. (2017), 'Private governance of global value chains from within: Lessons from and for transnational law', Transnational Legal Theory 8: 296-329.

Herberg, M. (2008), 'Global legal pluralism and interlegality: Environmental selfregulation in multinational enterprises as global law-making', in O. Dilling, M. Herberg, and G. Winter (eds), Responsible Business: Self-Governance and Law in Transnational Economic Transactions (Oxford: Hart Publishing), 17-40.

Kjaer, P. F. (2011), 'The concept of the political in the concept of transnational constitutionalism', in C. Joerges and R. Tommi (eds), After Globalization-New Patterns of Conflict and their Sociological and Legal Reconstruction (Oslo: Arena), 285-321.

Knöpfel, L. (2019), 'CSR communication in transnational human rights litigation against parent companies', TLI Think! 1/2019 Paper 1, available on SSRN: https://papers.ssrn.com/sol3/papers.cfm?abstract_id=3311545.

Levy, D. L. and R. Kaplan (2008), 'Corporate social responsibility and theories of global governance: Strategic contestation in global issue arenas', in A. Crane, A. McWilliams, D. Matten, J. Moon, and D. S. Siegel (eds), The Oxford Handbook of Corporate Social Responsibility (Oxford: Oxford University Press), 432-451.

Marchart, O. (2007), Post-Foundational Political Thought: Political Difference in Nancy, Lefort, Badiou and Laclau (Edinburgh: Edinburgh University Press).

Pistor, K. (2019), The Code of Capital: How the Law Creates Wealth and Inequality (Princeton, NJ: Princeton University Press).

Robé, J.-P. (2012), 'Being done with Milton Friedman', Accounting, Economics, and Law 2:2, Article 3.

Saage-Maaß, M. (2020), 'Between utopia and affirmation of status quo', Völkerrechtsblog-International Law and Legal Thought, 20 June 2020, https://voelkerrechtsblog .org/between-utopia-and-affirmation-of-the-status-quo/.

Sjåfjell, B., A. Johnston, L. Anker-Sorensen and D. Millon (2015), 'Shareholder primacy: The main barrier to sustainable companies', in B. Sjåfjell and B. J. Richardson (eds), Company Law and Sustainability: Legal Barriers and Opportunities (Cambridge: Cambridge University Press), 79-147.

Stout, L. (2008), 'Why we should stop teaching Dodge v. Ford' Virginia Law and Business Review 3: 163-190.

Teubner, G. (2011), 'Self-constitutionalizing transnational corporations? On the linkage of 'private' and 'public' corporate codes of conduct', Indiana Journal of Global Legal Studies 18, 17-38.

Teubner, G. (2012), Constitutional Fragments: Societal Constitutionalism in the Globalization (Oxford: Oxford University Press).

Zumbansen, P. (2019), “'Economic law” and the contractual constitution of global supply chains', Kritische Justiz 52: 670-695. 